\title{
The Arnold Berliner Award 2015
}

\author{
Sven Thatje ${ }^{1}$
}

Received: 22 March 2015 / Revised: 23 March 2015 / Accepted: 24 March 2015 /Published online: 8 April 2015

(C) Springer-Verlag Berlin Heidelberg 2015

It is my great pleasure to announce this year's winner of the Arnold Berliner Award, which is presented for the third time (Thatje 2013). The award is given to Dr. Stan Yavno (Tel Aviv University) and in recognition of his research article published in the The Science of Nature (formerly known as Naturwissenschaften) in 2014, which formed part of his doctoral study on the morphological plasticity of native and non-native pumpkinseed sunfish (Lepomis gibbosus) (Yavno et al. 2014).

Non-indigenous species are often exposed to ecosystems with unfamiliar species, and organisms that exhibit a high degree of phenotypic (morphological) plasticity may be able to deal better with novel competitors they encounter during range expansion. In his study, Stan Yavno and co-authors demonstrate differences in morphological plasticity using young-of-year pumpkinseed sunfish (L. gibbosus) from native North American and non-native European populations. These were kept with and without presence of bluegill sunfish (Lepomis macrochirus) and in order to present a competitive

Sven Thatje

svth@noc.soton.ac.uk

Ocean and Earth Science, University of Southampton, National Oceanography Centre, Southampton, European Way, Southampton SO14 3ZH, UK situation for food. All pumpkinseed populations exhibited dietary shifts towards more benthivorous ("bottom feeding") prey when held with bluegill. Phenotypic differences between North American and European populations were observed, for example, an increase in body size in pumkinseeds when kept with bluegill. Contrary to predictions, pumpkinseeds introduced to Europe exhibited lower levels of phenotypic plasticity than Canadian populations, suggesting that European pumpkinseeds have been more selected for (canalized) than their North American counterparts. These findings are peculiar because high levels of phenotypic plasticity are expected to facilitate range expansion of species into new areas, where biotic and abiotic conditions are unlike those from their source of origin. Whether or not phenotypic plasticity observed in the non-native observations is the result of a low genetic diversity in the invasive populations-and/or selection for phenotypic traits over multiple generations since their introduction-remains to be investigated.

The Arnold Berliner Award was established in recognition of the founding editor of Naturwissenschaften (now The Science of Nature, Thatje 2015) who led the journal for the exceptionally long period of 22 years (for biography, see O'Neil R 2015). The award is sponsored by the Springer Science + Business Media and is given annually for the best research article published in The Science of Nature during the previous calendar year (Thatje 2012). Criteria are excellence in science, originality, as well as aspects of interdisciplinarity, overall mirroring Arnold Berliner's motivation for initiating the 


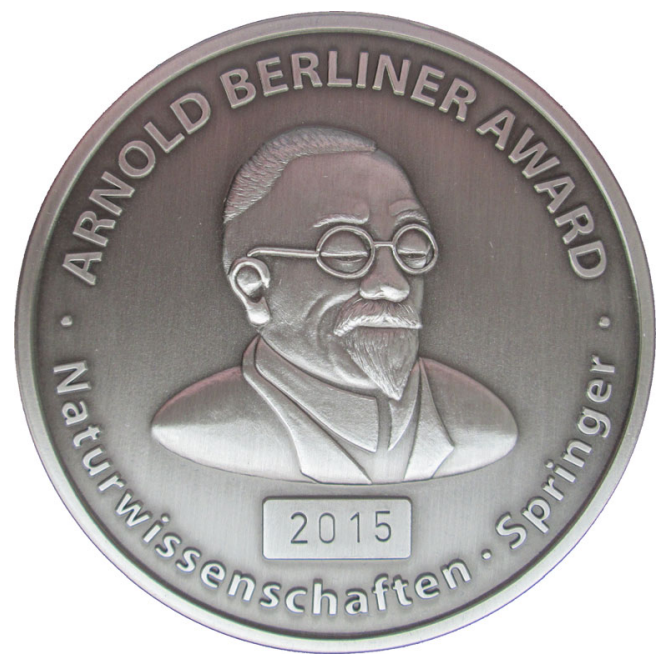

Fig. 1 The Arnold Berliner Award Medal. Arnold Berliner (1862-1942) was the founding editor of The Science of Nature (formerly known as Naturwissenschaften) and the journal's editor-in-chief from 1913 to 1935 (Thatje 2012, 2013)

journal. A jury, consisting of the board of editors and the editor-in-chief, selects the awardee. The award is marked with the Arnold Berliner Medal (Figs. 1 and 2) and is accompanied by a biennial subscription to the electronic edition of The Science of Nature, a 500-Euro voucher for Springer books, as well as a cash prize of 250 Euro.

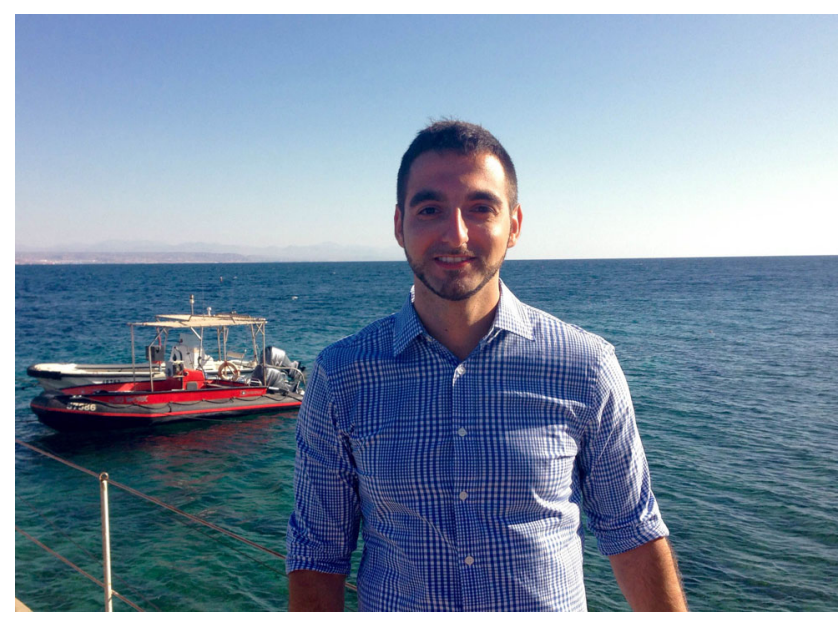

Fig. 2 Stan Yavno, winner of the Arnold Berliner Award 2015

\section{References}

O'Neil R (2015) The Mahler family in the rise \& fall of the Third Reich. MEREO self-publishing; ISBN: 978-1-909874-73-2

Thatje S (2012) Introducing the Arnold Berliner Award. Naturwissenschaften 99(9):675-676

Thatje S (2013) Dr. Arnold Berliner (1862-1942); physicist and founding editor of Naturwissenschaften. Naturwissenschaften 100:1105-1107

Thatje S (2015) The Science of Nature - a new era, a new name for Naturwissenschaften. Sci Nat 102:1252

Yavno S, Rooke AC, Fox FG (2014) Morphological change and phenotypic plasticity in native and non-native pumpkinseed sunfish in response to competition. Naturwissenschaften 101:479-492 